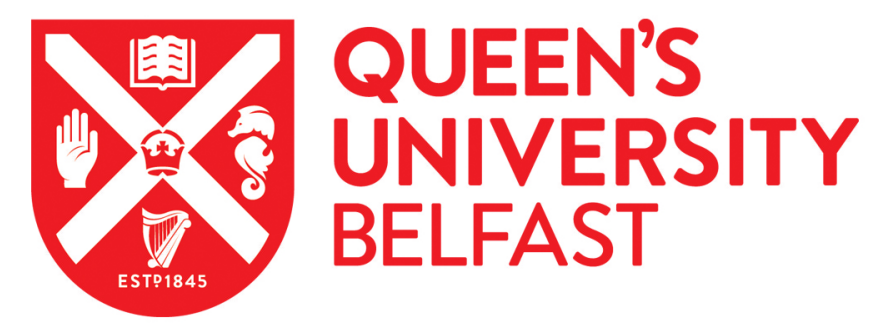

\title{
Homeless experiences and support needs of transgender people: A systematic review of the international evidence
}

McCann, E., \& Brown, M. J. (2021). Homeless experiences and support needs of transgender people: A systematic review of the international evidence. Journal of Nursing Management, 29(1), 85-94. https://doi.org/10.1111/jonm.13163

Published in:

Journal of Nursing Management

Document Version:

Peer reviewed version

Queen's University Belfast - Research Portal:

Link to publication record in Queen's University Belfast Research Portal

Publisher rights

() 2020 John Wiley \& Sons Ltd.

This work is made available online in accordance with the publisher's policies. Please refer to any applicable terms of use of the publisher.

\section{General rights}

Copyright for the publications made accessible via the Queen's University Belfast Research Portal is retained by the author(s) and / or other copyright owners and it is a condition of accessing these publications that users recognise and abide by the legal requirements associated with these rights.

Take down policy

The Research Portal is Queen's institutional repository that provides access to Queen's research output. Every effort has been made to ensure that content in the Research Portal does not infringe any person's rights, or applicable UK laws. If you discover content in the Research Portal that you believe breaches copyright or violates any law, please contact openaccess@qub.ac.uk. 


\section{Homeless experiences and support needs of transgender people: $A$ systematic review of the international evidence}

Running title: Transgender homeless supports

Edward McCann1 Michael J. Brown2

1. School of Nursing and Midwifery, Trinity College Dublin, Dublin, Ireland

2. School of Nursing and Midwifery, Queen's University Belfast, UK.

Acknowledgments: None.

Conflict of Interest: The authors declare no conflict of interest.

Funding: This research has received no funding.

Ethical Approval: Not required.

\section{Correspondence:}

Edward McCann

Email: mccanned@tcd.ie

Contact number: +353870552777

\section{Author Contributions:}

All authors meet the criteria for authorship. All entitled to authorship are listed as authors. No other authors were involved with this paper.

1. Have made substantial contributions to conception and design, or acquisition of literature, or analysis and interpretation of literature (EM and MB);

2. Been involved in drafting the manuscript or revising it critically for important intellectual content (EM and $\mathrm{MB})$;

3. Given final approval of the version to be published. Each author should have participated sufficiently in the work to take public responsibility for appropriate portions of the content (EM and MB);

4. Agreed to be accountable for all aspects of the work in ensuring that questions related to the accuracy or integrity of any part of the work are appropriately investigated and resolved (EM and $\mathrm{MB})$. 


\title{
Homeless experiences and support needs of transgender people: A systematic review of the international evidence
}

\author{
ABSTRACT \\ Aim: To examine the experiences and support needs of homeless transgender people by \\ synthesizing the existing evidence. \\ Background: Transgender people face many challenges in society in terms of people's \\ knowledge, understanding and acceptance of a person's gender identity. Evidence \\ regarding the homelessness experiences and available supports to transgender people remains \\ sparse.
}

Methods: A systematic review was undertaken and included qualitative and quantitative studies. A total of twelve papers were included in the review, utilising the PRISMA method. Methodological quality was evaluated using the Mixed Methods Assessment Tool (MMAT).

Results: Following analysis, the themes that emerged were (i) pathways into homelessness (ii) experiences whilst homeless, and (iii) routes out of homelessness.

Conclusion: It has become increasingly clear that the distinct needs of this group are complex and multifaceted. In order to adequately address the issues and concerns comprehensively, coordinated and effective collaborations need to be in place.

Implications for nursing management: Clinical nurses need to recognize and respond to the distinct needs of trans homeless people. Nurse managers need to provide leadership to promote the needs of homeless trans people and ensure that policies and procedures are in place that are responsive to issues and concerns.

KEYWORDS: Transgender, homeless, LGBTQ, human rights, social inclusion 


\section{INTRODUCTION}

Homelessness is a significant global public health issue with evolving international research evidence regarding transgender people (Ecker et al., 2019). The understanding of the issues impacting on their health and well-being and the factors leading to stigma and social exclusion are now attracting more attention (Montgomery et al., 2020; Sellers, 2018). Despite this increased focus, health, housing and social care practitioners may be unaware of the experiences and physical and psychosocial needs of transgender people.

\section{BACKGROUND}

Transgender is an 'umbrella' terms that describes people whose gender identity or expression does not match the sex assigned at birth. Transwomen were assigned male at birth and transmen female (National LGBT Health Education Center, 2016). Throughout this paper, the recognised and accepted term 'trans' is used to include and reflect the variety of identities, for example, gender non-conforming (GNC) and gender expansive, situated under the transgender 'umbrella' (Shelton et al., 2018; Kattari et al., 2020).

Homelessness can refer to people living on the streets, emergency shelters or in temporary accommodation such as squatting, couch surfing or in a vehicle (Crisis, 2020). In the United Kingdom (UK), LGBTQ+ people are 14 times more likely to become homeless compared to the general population, with $80 \%$ of respondents in a study stating that 'coming out' was a significant factor to becoming homeless (Albert Kennedy Trust, 2018). In the UK, one in four trans people have experienced homelessness, with twenty-five per cent of participants experiencing discrimination when buying or renting accommodation (Bachmann \& Gooch, 2018). Of the 1.6 million homeless youth in the United States (US), an estimated $20-40 \%$ are trans or LGBQ-identified, with one in five trans people in the US having 
experienced homelessness. Furthermore, more than one in ten have been ejected from their home due to their trans identity (National Center for Transgender Equality, 2020).

A general lack of awareness and responsiveness by practitioners and services to transspecific concerns has contributed to their discrimination, eviction and homelessness (Edmiston et al., 2016, Restar et al., 2020). The current literature evidences hate crimes (Haynes \& Schweppe, 2017), domestic abuse (Yerke \& DeFeo, 2016), victimization from colleagues or customers (Kattari et al., 2016), and poor family relationships resulting in homelessness (Klein $\&$ Golub, 2016). These issues can result in minority stress due to negative responses to psychosocial stressors (Testa et al., 2017). The psychological impact may manifest in mental illness, including anxiety, depression, alcohol and substance use and suicidality (Scheim et al., 2017; García-Andrade et al., 2019; Hughto et al., 2019). Some experience physical health conditions including human-immunodeficiency virus (HIV) and sexually transmitted infections (STIs) (Rosa et al., 2019). Homelessness therefore has a significant impact upon health and well-being with implications for nursing practice (Abeln \& Love 2019; Younas 2019). Despite all these issues, some trans people develop and build resilience that positively effects upon their health and well-being (Shankar et al., 2019).

\section{AIM AND QUESTIONS}

The aim of this systematic review is to more fully understand the homeless experiences of transgender people and determine their support needs and the service responses required.

The review questions were (i) what are the homeless experiences of transgender people? (ii) what are the specific support needs of transgender people? (iii) what are the services responses required concerning transgender people?

\section{METHODS}




\subsection{Design}

A recognised methodological process was used in the design of the systematic review that supported the effective identification and synthesis of qualitative and quantitative data sources (Amorataris \& Pearson 2014). The procedure involved searching the literature, evaluating the evidence, data analysis and synthesis of the included papers, and to present and integrate the findings into evidence-informed conclusions.

\subsection{Search strategy}

A subject Librarian was enlisted to assist with the literature search strategy and the searches were conducted in July 2020. The databases used in the search were CINAHL, MEDLINE, PsycINFO and Sociological Abstracts. The search terms used were: transgender* OR transsexual* OR gender identity OR gender dysphoria OR genderqueer OR nonbinary AND homeless. The data were accessed from inception to August 2020 and limited to academic journals and papers written in English. Two reviewers (*****) assessed the eligibility of the included studies against the inclusion criteria. The studies had to focus on the homeless experiences of transgender people. Any studies that did not meet the criteria were excluded. An example of the search strategy used in one electronic database is shown in Table 1.

***Insert Table 1 here $* * *$

\subsection{Search outcomes}

The searches revealed 283 hits across all of the databases. The PRISMA guidelines were used in the design and reporting of the systematic review and a flow chart is provided (Figure 1) that presents the results of the searches (Moher et al., 2015). A hand search was also 
conducted of the reference lists of the identified papers leaving a total of 12 papers included in the review.

***Insert Figure 1 here***

\subsection{Data extraction}

The data was extracted by two researchers $(* * * *)$ using a recognised process (Munn et al. 2014). The included papers and the relevant extracted data are presented in Table 2.

***Insert Table 2 here***

The twelve papers were derived from a total of seven studies with six conducted in the United States (US) and one in Canada. Four of the papers were derived from one data set involving a sample of transgender youth $(n=27)$ undertaken by Shelton and colleagues in New York. Similarly, two papers were associated with the outcome of another single study conducted by Begum and Kattari. Sample sizes of the included studies ranged between 3 and 721 participants. For data collection, a majority of studies $(n=8)$ used qualitative methods and four used quantitative methods. The data collection methods included surveys, measures, focus groups and individual interviews. Ethical approval was obtained for the studies. The study findings were clearly presented and recognised frameworks used as appropriate data collection methods. Robust approaches to analysis and syntheses were evident. The healthcare implications for transgender homeless people were elicited, presented and discussed.

\subsection{Quality assessment}


A recognized Mixed Methods Assessment Tool (MMAT) was used to assess the quality of the selected papers (Hong et al., 2018). Two reviewers (****) appraised the papers and a total of ten questions were applied to the data. Each item was rated as 'yes,' 'no,' and 'can't tell.' Each 'yes' response is scored 1 and summed for a total score. A 'yes' response indicated that a clear statement appeared in the paper that directly answered the question. 'No', indicated that the question was not addressed in the paper, and 'Can't tell', indicated that there was no clear statement relating to the question. Tables 3 and 4 contain the quality assessment outcomes.

*** Insert Tables 3 and 4 here $* * *$

\section{ANALYSIS}

The data was subjected to thematic analysis with the identified themes arranged into concepts and similarities and differences determined within and across the included studies. The themes were initially identified individually, then collectively verified and approved by the research team, hence addressing the potential for reviewer bias (Clarke and Braun, 2017).

\section{RESULTS}

Following data analysis, the themes that emerged were: (i) pathways into homelessness (ii) experiences whilst homeless, and (iii) routes out of homelessness.

\subsection{Pathways into homelessness}

There are a range of individual, multifaceted and complex factors that can lead trans people into homelessness. For some, the familial home can be a place of risk, lacking both physical safety and emotional support (Shelton, 2016). As a consequence of the person's developing 
and evolving trans identity, conflicts can arise in the home, school and workplace, playing an important role for some in the decision to leave or may lead to ejection from the familial home (Shelton \& Bond, 2017). During the evolution and development of their trans identity, many can experience stress, trauma, substance use, anxiety, depression, suicidality, isolation and a lack of social networks (Mokonogho et al., 2010; Fletcher et al., 2014; Johns et al., 2017). As part of the networks of supports and intervention options that could be made available to trans people and their families, there is a distinct lack of, and a need for early intervention work and prevention programmes (Begum \& Katarri, 2016; Blosnich et al., 2020; Glick et al., 2019; Shelton, 2016). Once homeless, trans people can experience a range of significant challenges that impact on their safety, health and well-being. Lacking access to financial support, some are forced into survival sex, leading to risks to their personal safety and physical and psychological health (Mokonogho et al., 2010; Shelton, 2015; Katarri \& Begum, 2016; Lyons et al., 2016). As a consequence of survival sex, many are at an increased risk of assault and exposure to HIV and STIs (Fletcher et al., 2014). For some homeless trans people, the situation is further complicated when trying to access healthcare services, such as primary care, sexual health and mental health, due to the lack of a permanent address. The situation of trying to access services and supports are further compounded by the cisgender presumption that pervades many services (Shelton, 2015). This can lead to some trans people, for example, concealing their trans identity in order to 'pass' as cisgender to enable access to homeless shelters and other supports (Shelton \& Bond, 2017). Others refer to 'gender policing' when seeking access to homeless shelters and supports, describing experiences of not presenting adequately, through their appearance or behaviour, to the sex assigned to them at birth (Lyons et al., 2016).

\subsection{Experiences whilst homeless}


The reasons that trans people become homeless are often complex and multifactorial. Once homeless, individuals can face challenges in finding somewhere appropriate to sleep and this may involve couch surfing, sleeping in a vehicle or sleeping in outside spaces (Begum \& Katarri, 2016). Whilst attempting to access homeless services and supports, some trans people continue to offer sex in return for a bed (Mokonogho et al., 2010; Fletcher et al., 2014; Shelton, 2016). Homeless trans youth may attempt to access homeless services and many report experiencing significant barriers whilst doing so. Individuals spoke about feeling fearful and unsafe in homeless shelters, with some trans people describing the accommodation as risky and dangerous (Shelton, 2016; Shelton \& Bond, 2017). Other important issues that have emerged included negative attitudes related to stigma and discrimination. Victimisation experiences, including bullying and harassment, were evident and the detrimental effect upon the person's physical health and emotional wellbeing was apparent for some trans people (Begum \& Katarri, 2016; Lyons et al., 2016). In some of the studies, cisgenderism was perceived to be the dominant presumption with trans people facing additional hostility and discrimination from either support staff or other service users within homeless services. There were expectations that trans people would conform to the gender 'norms' and alter their appearance and behaviour in order to 'fit in' and be accepted within the homelessness system or risk being denied or turned away (Shelton \& Bond, 2017; Shelton et al., 2017). In order to feel more safe and secure, trans homeless people recognised the importance of knowledgeable and skilled staff who possessed the necessary attitudes and competencies to provide adequate housing and supports tailored to the specific needs of trans people (Mokonogho et al., 2010; Fletcher et al., 2014; Begum \& Katarri, 2016; Katarri \& Begum, 2016; Blosnich et al., 2020).

The important role of knowledgeable and supportive case managers emerged as a finding in several studies, vital to ensure that trans people had access to culturally appropriate supports and advice (Begum \& Katarri, 2016; Blosnich et al., 2020). It is necessary that relevant policies 
and procedures are developed that are reflective of and sensitive to the housing, employment, health and wider support needs of trans people (Lyons et al., 2016; Shelton, 2015). In terms of additional sources of support identified in the studies, trans networks were seen as important in the development of self-identity, coping strategies and resilience (Shelton et al., 2017). Conversely, some LGB organisations were perceived to be discriminatory and judgmental, lacking in understanding and sensitivity towards trans people and their unique circumstances and concerns (Shelton, 2015).

\subsection{Routes out of homelessness}

For trans people experiencing homelessness, the situation was seen as temporary or transitory. Many described their hopes and aspirations towards a more positive envisioned future (Shelton, 2016). Their expectations included a home that provided comfort, safety, free-gender expression and a place 'to be ones-self' (Shelton et al., 2017). A significant issue for many trans people was the need for employment and, resulting from this, financial independence (Shelton et al., 2017). However, there were barriers to achieving this due to, for example, the need for a permanent address as well as more practical issues, such as access to space and time for grooming, to adequately prepare for a job interview (Shelton \& Bond, 2017). Central to helping exit homelessness and homeless services, was the need for networks that are sensitive to the specific needs and concerns of trans people. Access to supports throughout the transition out of homeless services and on into a new life was seen as crucial (Lyons et al., 2016; Johns et al., 2017).

To help ensure that the specific needs of trans people are recognised and fully respected when exiting homelessness, there is a need for services upon which they may require to access for support to have in place policies and procedures that are reflective and inclusive of their needs (Begum \& Katarri, 2016; Lyons et al., 2016). Training and education were also seen as 
necessary to help staff in housing, employment, health and social care services to develop the knowledge, skills, understanding and positive attitudes regarding the distinct needs of trans people (Mokonogho et al., 2010; Begum \& Katarri, 2016; Blosnich et al., 2020; Katarri \& Begum, 2016). Having exited homelessness, access to services and interventions to enable trans people to re-engage with families and friends was viewed as an important missing element in available supports (Shelton \& Bond, 2017).

\section{DISCUSSION}

This systematic review has set out the scope and extent of the needs and challenges experienced by homeless trans people. The main findings from this review set out the complex and multifaceted needs of this population, highlighting the need for a sustained and on-going focus across agencies and services to ensure that specific support needs are recognised and comprehensively addressed. Policies need to be fully reflective of the requirements of trans people. Housing, social work, primary care, mental health, sexual health and nursing policies need to clearly articulate their contributions in working collaboratively with the trans community to ensure service responses are comprehensive and coordinated. Failure to respond effectively will widen the health inequalities gap, compound social exclusion and the further marginalisation of this population (Thomas et al., 2017).

Education initiatives need to be developed and provided for trans people and their families and friends as part of comprehensive provision that aims to tackle cisgenderism and transphobia (Stroumsa et al., 2019). Education programmes at undergraduate and postgraduate levels for professionals need to ensure that the issues and concerns of trans people are incorporated and embedded effectively. There should be an ethos that promotes person-centred approaches to care and support, builds confidence and challenges transphobia (Wylie et al., 2016). There is scope for continuing education development to be undertaken and delivered in 
partnership with trans people. It can be provided across service agencies, thereby developing a shared understanding of needs and build opportunities for multiagency collaborations (Cream et al., 2020). While the research evidence base on the needs of homeless trans people is evolving, it remains limited. There is a need for future research to be co-produced and conducted with trans homeless people, thereby seeking to ensure that their needs and concerns are at the centre of any research studies.

\section{LIMITATIONS}

Several limitations have been identified from this review including the dearth of research studies that have been executed outside of the USA and Canada. This is important as policies, and housing and other care services and provision may differ. There is a distinct lack of multicentred international studies or longitudinal studies examining the support needs of transgender homeless populations and subpopulations within the trans community such as people with disabilities. The authors have attempted to be rigorous in undertaking the review and recognise that potential for subjectivity in the process.

\section{CONCLUSIONS}

This systematic review of the research evidence highlights the views and experiences of transgender homeless people and identifies their unique support and service needs. The priorities for housing, health and social services have been elucidated and documented. It has become increasingly clear that the distinct needs of this group are complex. As a consequence of this, there are important implications for nurse managers and clinical nurses. Nurse managers need to recognise their responsibility to provide leadership in policy implementation, shaping nursing practice and working collaboratively with nurse educators to ensure that the workforce has access to the necessary education and practice development. Clinical nurses 
need to ensure that their assessments are culturally sensitive by incorporating the needs of trans people and through the provision of care and support that is person-centred, responsive and appropriate. These are necessary to adequately address the issues and concerns comprehensively, through the provision of coordinated and effective collaborations between governmental and non-governmental agencies.

\section{IMPLICATIONS FOR NURSING MANAGEMENT}

Given the extent of the needs of homeless trans people and the evidence of the scope of their health needs, there are important responses required from nurses. Clinical nurses are frequently the first point of contact with health services and they are in a prime position to respond to the needs of homeless trans people. There is an opportunity to ensure that the housing, health and social care needs and concerns of trans people are reflected within holistic nursing assessments, case formulation and care plans (McDowell et al., 2016). Clinical nurses are well placed to work collaboratively with key agencies necessary in the care and support of homeless trans people. They can contribute to the provision of coordinated care, proactively promoting and leading anti-discriminatory practice to address transphobia (Mizock \& Mueser, 2014). There are opportunities clinical nurses to develop their knowledge, skills and confidence in the delivery of treatments and interventions necessary to meet the needs of homeless trans people (García-Acosta et al., 2019). Nurse managers have important roles to play in ensuring that clinical nurses access education and practice development that develops their knowledge and skills of the trans community, and specifically those experiencing homelessness (Abeln \& Love, 2019). Working collaboratively across nursing and wider health services and in partnership with other agencies such as housing and social work, is an area where nurse managers can provide leadership to ensure that the needs of homeless trans people are effectively integrated within policies and procedures. 


\section{References}

Abeln, B. \& Love, R. (2019). Bridging the gap of mental health inequalities in the transgender population: the role of nursing education. Issues in Mental Health Nursing, 40(6), 482-5.

Albert Kennedy Trust (2018). Strategy 2018-2021: Preventing LGBTQ+ youth homelessness, because no young person should have to choose between a safe home and being who they are. London: Albert Kennedy Trust.

Aromataris E, Pearson A. (2014) The systematic review: An overview. AJN The American Journal of Nursing, 114(3), 53-8.

Bachmann, C. L. \& Gooch, B. (2018). LGBT in Britain: trans report. London: Stonewall.

Begun, S. \& Kattari, S.K. (2016). Conforming for survival: Associations between transgender visual conformity/passing and homelessness experiences. Journal of Gay \& Lesbian Social Services, 28(1), 54-66, DOI: 10.1080/10538720.2016.1125821

Blosnich, J.R., Rodriguez, K.L., Hruska, K.L., Klima, G.J., Vazzano, J.K., Shipherd, J.C., Kauth, M.R. \& Montgomery, A.E. (2020). "Get people out of bad situations sooner": exploring transgender and cisgender veterans' experiences using permanent supportive housing. Housing and Society, 1-19.

Clarke, V. \& Braun, V. (2017). Thematic analysis. The Journal of Positive Psychology, 12(3), 297-298.

Cream, J., Fenney, D., Williams, E., Baylis, A., Dahir, S. \& Wyatt, H. (2020). Delivering Health and Care for People Who Sleep Rough-Going Above and Beyond. The King's Fund, London, available at: https://www. kingsfund. org. uk/publications/delivering-health-carepeople-sleep-rough (accessed 18 August 2020).

Crisis (2020). Homeless Knowledge Hub https://www.crisis.org.uk/endinghomelessness/homelessness-knowledge-hub/ Accessed 1 August 2020.

Ecker, J., Aubry, T., \& Sylvestre, J. (2019). A review of the literature on LGBTQ adults who experience homelessness. Journal of Homosexuality, 66(3), 297-323.

Edmiston, E. K., Donald, C. A., Sattler, A. R., Peebles, J. K., Ehrenfeld, J. M., \& Eckstrand, K. L. (2016). Opportunities and gaps in primary care preventative health services for transgender patients: a systematic review. Transgender Health, 1(1), 216-230.

Fletcher, J. B., Kisler, K. A., \& Reback, C. J. (2014). Housing status and HIV risk behaviors among transgender women in Los Angeles. Archives of Sexual Behavior, 43(8), 1651-1661. 
Glick, J. L., Lopez, A., Pollock, M., \& Theall, K. P. (2019). "Housing Insecurity Seems to Almost Go Hand in Hand with Being Trans": Housing Stress among Transgender and Gender Non-conforming Individuals in New Orleans. Journal of Urban Health, 96(5), 751-759.

García-Acosta, J.M., Castro-Peraza, M.E., Arias Rodriguez, Á., Perez-Cánovas, M.L., SosaAlvarez, M.I., Llabrés-Solé, R., Perdomo-Hernández, A.M. \& Lorenzo-Rocha, N.D. (2019). Impact of a Formative Program on Transgender Healthcare for Nursing Students and Health Professionals. Quasi-Experimental Intervention Study. International Journal of Environmental Research and Public Health 16 (17), 3205.

García-Andrade, R. F., Rendón-Luna, B. S., Martínez, V. V., De Meneses, E. M. T. \& Prieto, B. R. (2019). Transgender Women with Severe Mental Illness and Homelessness: A Retrospective Case Series. Open Journal of Social Sciences, 7(08), 405.

Haynes, A., \& Schweppe, J. (2017). LGB and T? The specificity of anti-transgender hate crime. In Critical Perspectives on Hate Crime (pp. 111-136). Palgrave Macmillan, London.

Hong, QN., Pluye, P., Fàbregues, S., Bartlett, G., Boardman, F., Cargo, M., Dagenais, P., Gagnon, M-P., Griffiths, F., Nicolau, B., O'Cathain, A., Rousseau, M-C \& Vedel I. (2018). Mixed Methods Appraisal Tool (MMAT), version 2018. Registration of Copyright (\#1148552), Canadian Intellectual Property Office, Industry Canada.

Hughto, J. M. W., Reisner, S. L., Kershaw, T. S., Altice, F. L., Biello, K. B., Mimiaga, M. J., ... \& Pachankis, J. E. (2019). A multisite, longitudinal study of risk factors for incarceration and impact on mental health and substance use among young transgender women in the USA. Journal of Public Health, 41(1), 100-109.

Johns, E. A., Jin, H., Auerswald, C. L., \& Wilson, E. C. (2017). Sociodemographic factors associated with trans* female youth's access to health care in the San Francisco Bay Area. Journal of Adolescent Health, 61(2), 259-261.

Kattari, S. K., Whitfield, D. L., Walls, N. E., Langenderfer-Magruder, L., \& Ramos, D. (2016). Policing gender through housing and employment discrimination: comparison of discrimination experiences of transgender and cisgender LGBQ individuals. Journal of the Society for Social Work and Research, 7(3), 427-447.

Kattari, S. K., \& Begun, S. (2016). On the margins of marginalized: Transgender homelessness and survival sex. Affilia, 32(1), 92-103.

Kattari, S. K., Brittain, D. R., Markus, A. R., \& Hall, K. C. (2020). Expanding Women's Health Practitioners and Researchers' Understanding of Transgender/Nonbinary Health Issues. Women's Health Issues, 30(1), 3-6.

Klein, A., \& Golub, S. A. (2016). Family rejection as a predictor of suicide attempts and substance misuse among transgender and gender nonconforming adults. LGBT Health, 3(3), 193-199.

Lyons, T., Krüsi, A., Pierre, L., Smith, A., Small, W., \& Shannon, K. (2016). Experiences of trans women and two-spirit persons accessing women-specific health and housing services in a downtown neighborhood of Vancouver, Canada. LGBT Health, 3(5), 373-378. 
McDowell, A. \& Bower, K.M. (2016). Transgender health care for nurses: An innovative approach to diversifying nursing curricula to address health inequities. Journal of Nursing Education, 55(8), 476-479.

Mizock, L. \& Mueser, K.T. (2014). Employment, mental health, internalized stigma, and coping with transphobia among transgender individuals. Psychology of Sexual Orientation and Gender Diversity 1(2), 146.

Moher, D., Shamseer, L., Clarke, M., Ghersi, D., Liberati, A, Petticrew, M., Shekelle, P., \& Stewart L.A. (2015). Prefered reporting items for systematic review and meta-analysis protocols (PRISMA-P) 2015 statement. Systematic Reviews 4(1), 1-9.

Mokonogho, J., Mittal, S., \& Quitangon, G. (2010). Treating the transgender homeless population: Experiences during residency training. Journal of Gay \& Lesbian Mental Health, 14(4), 346-354.

Montgomery, A. E., Shipherd, J. C., Kauth, M. R., Harris, K. W., \& Blosnich, J. R. (2020). Use of Veterans Health Administration Homeless Programs Among Transgender and NonTransgender Veterans Experiencing Self-Reported Housing Instability. Journal of Health Care for the Poor and Underserved, 31(2), 909-919.

Munn, Z., Tufanaru, C. \& Aromataris, E. (2014). JBI's systematic reviews: data extraction and synthesis. American Journal of Nursing, 114 (7), 49-54.

National Center for Transgender Equality (2020). https://transequality.org/issues/housinghomelessness (Accessed 16 August 2020).

National LGBT Health Education Center (2016). Affirmative care for transgender and gender non-conforming people: Best practices for front-line health care staff. Boston,MA: The Fenway Institute.

Restar, A. J., Sherwood, J., Edeza, A., Collins, C., \& Operario, D. (2020). Expanding GenderBased Health Equity Framework for Transgender Populations. Transgender Health.

Rosa, D.F., Carvalho, M.V., Pereira, N.R., Rocha, N.T., Neves, V.R. \& Rosa, A.D. (2019). Nursing Care for the transgender population: genders from the perspective of professional practice. Revista Brasileira de Enfermagem 72, 299-306.

Scheim, A. I., Bauer, G. R., \& Shokoohi, M. (2017). Drug use among transgender people in Ontario, Canada: Disparities and associations with social exclusion. Addictive Behaviors, 72, 151-158.

Sellers, M. D. (2018). Absent inclusion polices: Problems facing homeless transgender youth. Public Integrity, 20(6), 625-639.

Shankar, S., Gogosis, E., Palepu, A., Gadermann, A. M., \& Hwang, S. W. (2019). “I Haven’t Given Up and I'm Not Gonna": A Phenomenographic Exploration of Resilience Among Individuals Experiencing Homelessness. Qualitative Health Research, 29 (13), 1850-1861. 
Shelton, J. (2015). Transgender youth homelessness: Understanding programmatic barriers through the lens of cisgenderism. Children and Youth Services Review, 59, 10-18.

Shelton, J. (2016). Reframing risk for transgender and gender-expansive young people experiencing homelessness. Journal of Gay \& Lesbian Social Services, 28(4), 277-291.

Shelton, J., \& Bond, L. (2017). "It Just Never Worked Out": How Transgender and Gender Expansive Youth Understand their Pathways into Homelessness. Families in Society, 98(4), 284-291.

Shelton, J., Wagaman, M. A., Small, L., \& Abramovich, A. (2017). I'm more driven now: Resilience and resistance among transgender and gender expansive youth and young adults experiencing homelessness. International Journal of Transgenderism, 19(2), 144-157.

Stroumsa, D., Shires, D.A., Richardson, C.R., Jaffee, K.D. \& Woodford, M.R. (2019). Transphobia rather than education predicts provider knowledge of transgender health care. Medical Education, 53(4), 98-407.

Testa, R. J., Michaels, M. S., Bliss, W., Rogers, M. L., Balsam, K. F., \& Joiner, T. (2017). Suicidal ideation in transgender people: gender minority stress and interpersonal theory factors. Journal of Abnormal Psychology, 126(1), 125.

Thomas, R., Pega, F., Khosla, R., Verster, A., Hana, T., \& Say, L. (2017). Ensuring an inclusive global health agenda for transgender people. Bulletin of the World Health Organization, 95(2), 154.

Wylie, K., Knudson, G., Khan, S.I., Bonierbale, M., Watanyusakul, S. \& Baral, S. (2016). Serving transgender people: clinical care considerations and service delivery models in transgender health. The Lancet, 388(10042), 401-411.

Yerke, A. F., \& DeFeo, J. (2016). Redefining intimate partner violence beyond the binary to include transgender people. Journal of Family Violence, 31(8), 975-979.

Younas A. (2019). Lesbian, gay, bisexual and transgender-related inequalities within nursing: A neglected research area. Journal of Advanced Nursing, 75(7), 1374-6. 
Figure 1: PRISMA Flow Diagram with search results
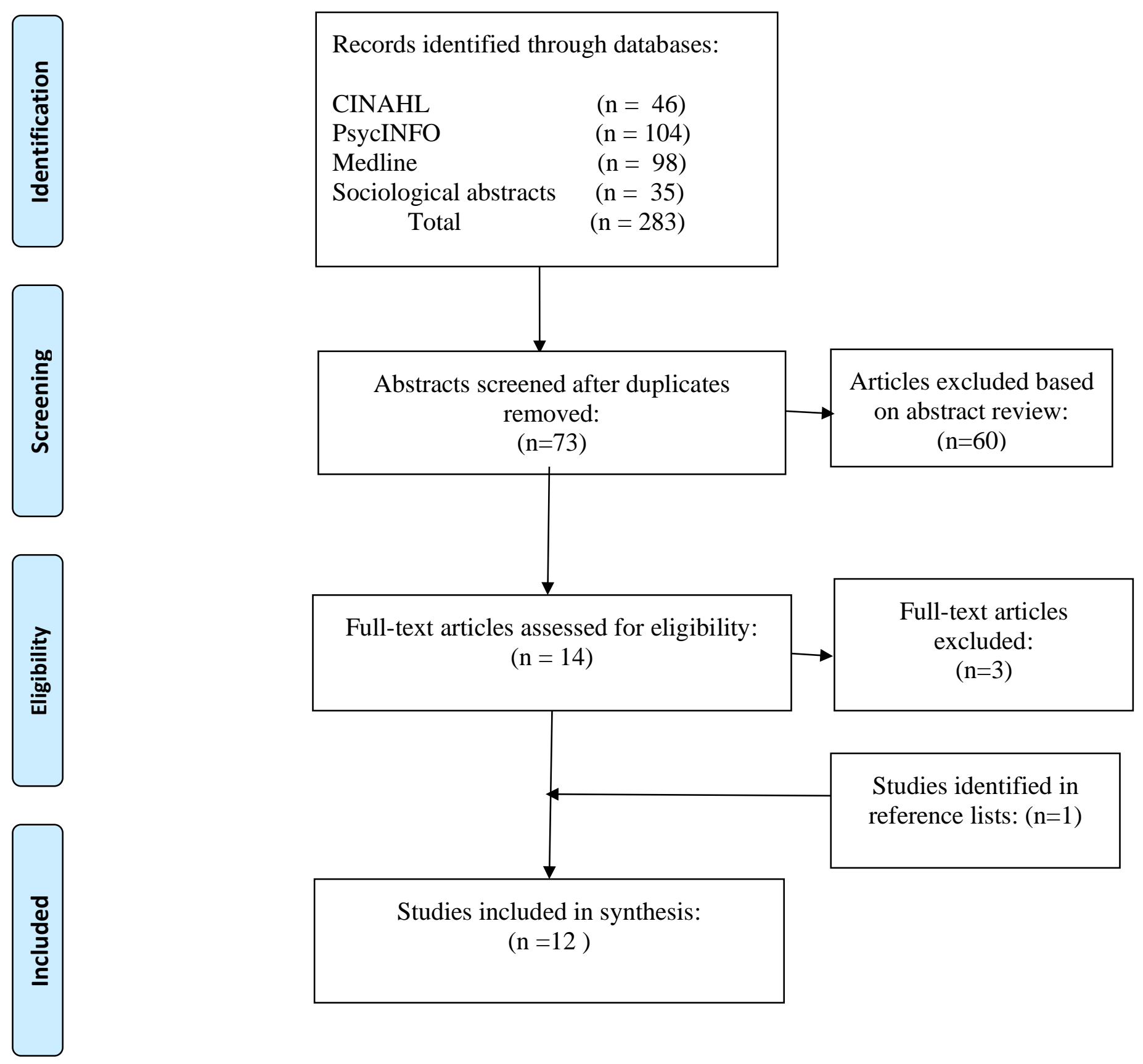
Table 1: PsycINFO search strategy and results

\begin{tabular}{|l|l|c|}
\hline $\begin{array}{l}\text { Search } \\
\text { code }\end{array}$ & Query & Results \\
\hline S1 & transgender* & 5,146 \\
\hline S2 & transsexual* & 1,290 \\
\hline S3 & gender dysphoria & 525 \\
\hline S4 & genderqueer & 54 \\
\hline S5 & non-binary & 102 \\
\hline S6 & Homeless* & 10,292 \\
\hline S7 & S1 OR S2 OR S3 OR S4 OR S5 & 6,052 \\
\hline S8 & S6 AND S7 & 112 \\
\hline S9 & $\begin{array}{l}\text { Limiters: English and Academic } \\
\text { Journals }\end{array}$ & 104 \\
\hline
\end{tabular}


Table 2: Papers included in the review $(n=12)$

\begin{tabular}{|c|c|c|c|c|c|}
\hline $\begin{array}{l}\text { Study Citation } \\
\text { and Country }\end{array}$ & Aims & Sample & $\begin{array}{l}\text { Data collection } \\
\text { method }\end{array}$ & Key Findings & Recommendations \\
\hline $\begin{array}{l}\text { Begun \& Katarri } \\
\text { (2016) } \\
\text { USA }\end{array}$ & $\begin{array}{l}\text { Explore associations } \\
\text { between trans } \\
\text { passing and } \\
\text { homeless } \\
\text { experiences. }\end{array}$ & 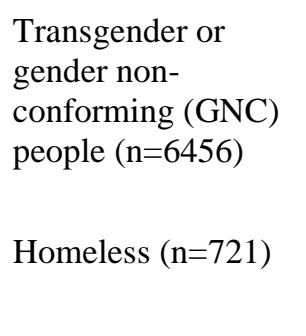 & National Survey & $\begin{array}{l}\text { Lower trans visual conformity } \\
\text { or passing is positively related } \\
\text { to homelessness and negative } \\
\text { experiences in homeless } \\
\text { shelters including harassment } \\
\text { and violence. Younger people } \\
\text { and male to female trans likely } \\
\text { to experience homelessness. }\end{array}$ & $\begin{array}{l}\text { Professionals need to have } \\
\text { greater knowledge and a better } \\
\text { grasp of trans-specific issues. } \\
\text { Culturally competent education } \\
\text { and clear policies required to } \\
\text { guide supports and interventions. }\end{array}$ \\
\hline $\begin{array}{l}\text { Blosnich et al. } \\
(2020) \\
\text { USA }\end{array}$ & $\begin{array}{l}\text { Explore facilitators } \\
\text { and barriers to } \\
\text { accessing housing } \\
\text { assistance among } \\
\text { transgender and } \\
\text { cisgender veterans. }\end{array}$ & $\begin{array}{l}\text { Cisgender men } \\
(\mathrm{n}=17) \\
\text { Cisgender women } \\
(\mathrm{n}=14) \\
\text { Transgender women } \\
(\mathrm{n}=17)\end{array}$ & Telephone interviews & $\begin{array}{l}\text { Case managers play a key role } \\
\text { in supporting access to } \\
\text { housing. Veterans unable to } \\
\text { receive services until homeless, } \\
\text { with landlords reluctant to rent } \\
\text { to veterans with substance use } \\
\text { histories. Trans women } \\
\text { veterans experience specific } \\
\text { challenges related to gender- } \\
\text { specific shelter experiences. }\end{array}$ & $\begin{array}{l}\text { Training is required for case } \\
\text { managers regarding the specific } \\
\text { needs of transgender service } \\
\text { users and applied to services for } \\
\text { other trans homeless groups. } \\
\text { Further surveys and interviews } \\
\text { are required involving case } \\
\text { managers to identify strategies } \\
\text { that help transgender service } \\
\text { users navigate homeless } \\
\text { services. }\end{array}$ \\
\hline $\begin{array}{l}\text { Fletcher et al. } \\
(2014) \\
\text { USA }\end{array}$ & $\begin{array}{l}\text { Examine the } \\
\text { association between } \\
\text { housing status and } \\
\text { HIV in transwomen } \\
\text { in Los Angeles. }\end{array}$ & $\begin{array}{l}\text { Transwomen } \\
(\mathrm{n}=517)\end{array}$ & Survey and measures & $\begin{array}{l}35 \% \text { of sample were homeless } \\
\text { with Hispanic and African- } \\
\text { American most common. } \\
\text { Homeless transwomen engaged } \\
\text { in more illicit drug use. Housed } \\
\text { women had higher rates of } \\
\text { illegal hormone injections. Sex }\end{array}$ & $\begin{array}{l}\text { HIV prevention programmes } \\
\text { should identify and tailor } \\
\text { services to different levels of } \\
\text { housing status in transwomen. }\end{array}$ \\
\hline
\end{tabular}




\begin{tabular}{|c|c|c|c|c|c|}
\hline & & & & $\begin{array}{l}\text { work high in the sample. } \\
(49 \%) \text {. Greater HIV risk in } \\
\text { homeless transwomen. }\end{array}$ & \\
\hline $\begin{array}{l}\text { Glick et al. (2019) } \\
\text { USA }\end{array}$ & $\begin{array}{l}\text { Explore housing } \\
\text { insecurity and stress } \\
\text { among trans and } \\
\text { GNC people. }\end{array}$ & $\begin{array}{l}\text { Trans and GNC } \\
\text { people }(n=17)\end{array}$ & Interviews & $\begin{array}{l}\text { Intersectional stigma and } \\
\text { discrimination, and area } \\
\text { gentrification led to insecurities } \\
\text { and lack of affordable housing. } \\
\text { Black trans respondents } \\
\text { experienced greater } \\
\text { vulnerabilities. Social support } \\
\text { and queer family structures } \\
\text { were important factors for } \\
\text { resilience, coping and survival. }\end{array}$ & $\begin{array}{l}\text { Need to identify the barriers to } \\
\text { safe, accessible and stable } \\
\text { housing. Need to increase } \\
\text { resources for trans/GNC housing } \\
\text { access, supports and } \\
\text { interventions that address } \\
\text { cyclical discrimination, housing } \\
\text { and employment issues and } \\
\text { concerns. Need to more fully } \\
\text { understand the impact upon } \\
\text { health. }\end{array}$ \\
\hline $\begin{array}{l}\text { Johns et al. (2017) } \\
\text { USA }\end{array}$ & $\begin{array}{l}\text { Explore trans female } \\
\text { youth's access to } \\
\text { health care in San } \\
\text { Francisco. }\end{array}$ & $\begin{array}{l}\text { Trans female youth } \\
(\mathrm{n}=250)\end{array}$ & Survey & $\begin{array}{l}\text { Discrimination and stigma by } \\
\text { providers and a person's } \\
\text { homeless status were the } \\
\text { greatest barriers to accessing } \\
\text { medical and mental healthcare. } \\
26 \% \text { of the sample were living } \\
\text { in unstable housing and } 56 \% \\
\text { had history of unstable } \\
\text { housing. }\end{array}$ & $\begin{array}{l}\text { Need for interventions to address } \\
\text { discrimination and unstable } \\
\text { housing to enable better access } \\
\text { to appropriate healthcare } \\
\text { supports and services and } \\
\text { facilitate the transition to } \\
\text { adulthood. }\end{array}$ \\
\hline $\begin{array}{l}\text { Kattari \& Begun } \\
(2016) \\
\text { USA }\end{array}$ & $\begin{array}{l}\text { Examine trans/GNC } \\
\text { homelessness and } \\
\text { survival sex. }\end{array}$ & $\begin{array}{l}\text { Transgender or } \\
\text { gender non- } \\
\text { conforming }(\mathrm{GNC}) \\
\text { people }(\mathrm{n}=6456) \\
\text { Homeless }(\mathrm{n}=721)\end{array}$ & National Survey & $\begin{array}{l}11 \% \text { of sample were homeless. } \\
11 \% \text { of had engaged in survival } \\
\text { sex. } 7 \% \text { had sex to pay for } \\
\text { rent. Temporary } \\
\text { accommodation used by } 16 \% \text {. } \\
\text { Safety and risk concerns in } \\
\text { shelters was } 42 \% \text {. Many forced } \\
\text { to present as the wrong gender }\end{array}$ & $\begin{array}{l}\text { Provide education and training } \\
\text { in trans-affirmative practices and } \\
\text { advocacy initiatives. Address } \\
\text { access, discrimination, } \\
\text { harassment and assault in } \\
\text { homeless shelters. Further } \\
\text { research required regarding }\end{array}$ \\
\hline
\end{tabular}




\begin{tabular}{|c|c|c|c|c|c|}
\hline & & & & $\begin{array}{l}\text { to stay in the shelter }(40 \%) \text { and } \\
39 \% \text { to feel safe. People from } \\
\text { BME backgrounds more likely } \\
\text { to engage in survival sex. }\end{array}$ & $\begin{array}{l}\text { housing insecurity and survival } \\
\text { sex by trans/GNC people. }\end{array}$ \\
\hline $\begin{array}{l}\text { Lyons et al. (2016) } \\
\text { Canada }\end{array}$ & $\begin{array}{l}\text { Examine health and } \\
\text { housing experiences } \\
\text { of transwomen and } \\
\text { two-spirited people. }\end{array}$ & $\begin{array}{l}\text { Transwomen and } \\
\text { two-spirited people } \\
(n-32)\end{array}$ & Interviews & $\begin{array}{l}\text { Discrimination experienced re } \\
\text { gender identity and gender } \\
\text { expression. Lack of staff } \\
\text { intervention for harassment. } \\
\text { Transwomen felt unsafe and } \\
\text { unsupported. Gender 'policing' } \\
\text { evident. Homelessness } \\
\text { increased threat of violence and } \\
\text { victimization. }\end{array}$ & $\begin{array}{l}\text { Need to improve accessibility to } \\
\text { appropriate supports and } \\
\text { services. Policy developments } \\
\text { required around anti-stigma and } \\
\text { trans-inclusive issues. Gender } \\
\text { inclusive policy needed } \\
\text { regarding accessing services and } \\
\text { support networks. }\end{array}$ \\
\hline $\begin{array}{l}\text { Mokonogho et al. } \\
(2010) \\
\text { USA }\end{array}$ & $\begin{array}{l}\text { Describe the } \\
\text { treatment of } \\
\text { transgender } \\
\text { homeless people by } \\
\text { trainee psychiatrists. }\end{array}$ & $\begin{array}{l}\text { Transgender people } \\
(\mathrm{n}=3)\end{array}$ & Interviews & $\begin{array}{l}\text { Issues included mood and } \\
\text { psychotic disorders. High rates } \\
\text { of substance misuse and post- } \\
\text { traumatic stress disorder. } \\
\text { Survival sex experiences } \\
\text { described. Poor social supports, } \\
\text { treatment adherence, } \\
\text { prostitution and imprisonment. }\end{array}$ & $\begin{array}{l}\text { Need effective engagement with } \\
\text { treatment teams and good } \\
\text { therapeutic alliance. More } \\
\text { research needed on the effects of } \\
\text { hormone therapy and } \\
\text { reassignment surgery on health } \\
\text { and well-being. Trainee } \\
\text { psychiatrists require exposure to } \\
\text { trans populations under } \\
\text { supervision from experienced } \\
\text { psychiatrists in trauma and } \\
\text { substance misuse. }\end{array}$ \\
\hline $\begin{array}{l}\text { Shelton (2015) } \\
\text { USA }\end{array}$ & $\begin{array}{l}\text { Explore barriers in } \\
\text { transgender youth } \\
\text { homelessness } \\
\text { programmes. }\end{array}$ & $\begin{array}{l}\text { Transgender youth } \\
(\mathrm{n}=27)\end{array}$ & Interviews & $\begin{array}{l}\text { Barriers to accessing homeless } \\
\text { services included: rejection and } \\
\text { harassment, stigma and } \\
\text { discrimination, and systemic } \\
\text { issues and concerns including } \\
\text { safety aspects. Fear, frustration }\end{array}$ & $\begin{array}{l}\text { Need more trans-affirmative } \\
\text { programmes and supports that } \\
\text { are accessible and responsive to } \\
\text { individual needs. Policies and } \\
\text { practices need to be in place to } \\
\text { support non-cisgender }\end{array}$ \\
\hline
\end{tabular}




\begin{tabular}{|c|c|c|c|c|c|}
\hline & & & & $\begin{array}{l}\text { and uncertainty felt by some. } \\
\text { Trans discrimination } \\
\text { experienced within LGB } \\
\text { communities. Privacy and } \\
\text { space an important } \\
\text { consideration in housing } \\
\text { programmes. Homelessness } \\
\text { negatively impacts } \\
\text { employment opportunities. }\end{array}$ & $\begin{array}{l}\text { approaches including physical } \\
\text { and emotional safety. }\end{array}$ \\
\hline $\begin{array}{l}\text { Shelton (2016) } \\
\text { USA }\end{array}$ & $\begin{array}{l}\text { Examine risk } \\
\text { experiences for } \\
\text { homeless } \\
\text { transgender youth. }\end{array}$ & $\begin{array}{l}\text { Transgender youth } \\
(\mathrm{n}=27)\end{array}$ & Interviews & $\begin{array}{l}\text { Family home seen as risky for } \\
\text { some - unstable, dangerous and } \\
\text { risky. Sex work undertaken by } \\
\text { some to survive. Transgender } \\
\text { community perceived as } \\
\text { supportive, validating, and } \\
\text { helped develop skills and } \\
\text { resilience. Many felt proud of } \\
\text { their achievements through } \\
\text { homeless experiences through } \\
\text { affirmation, connection and } \\
\text { growth. }\end{array}$ & $\begin{array}{l}\text { Need a holistic understanding of } \\
\text { experiences. Build on strengths } \\
\text { and positive experiences with } \\
\text { appropriate prevention and } \\
\text { intervention strategies. Family } \\
\text { education and support needed. } \\
\text { Policies of inclusion and non- } \\
\text { discrimination required. } \\
\text { Longitudinal research studies } \\
\text { needed to further highlight } \\
\text { barriers and possible solutions. }\end{array}$ \\
\hline $\begin{array}{l}\text { Shelton \& Bond } \\
\text { (2017) } \\
\text { USA }\end{array}$ & $\begin{array}{l}\text { Explore transgender } \\
\text { youth pathways into } \\
\text { homelessness. }\end{array}$ & $\begin{array}{l}\text { Transgender youth } \\
(\mathrm{n}=27)\end{array}$ & Interviews & $\begin{array}{l}\text { A majority }(\mathrm{n}=25) \text { attributed } \\
\text { gender expression to their } \\
\text { homelessness. Family rejection } \\
\text { re GNC identity led to } \\
\text { homelessness }((\mathrm{n}=18) \text {. Themes } \\
\text { were: the journey, gender } \\
\text { designations and housing } \\
\text { status, the other side of risk, } \\
\text { programs, and the unique needs } \\
\text { of transgender young people. } \\
\text { Barriers to accessing }\end{array}$ & $\begin{array}{l}\text { Family work needed. } \\
\text { Transgender affirming support } \\
\text { services required with better } \\
\text { access. Need to address } \\
\text { cisgenderism. Provide greater } \\
\text { housing options with } \\
\text { knowledgeable and skilled staff. } \\
\text { More supports at school needed } \\
\text { and transgender-affirming } \\
\text { environments within youth } \\
\text { services. More research required }\end{array}$ \\
\hline
\end{tabular}




\begin{tabular}{|c|c|c|c|c|c|}
\hline & & & & $\begin{array}{l}\text { employment need to be } \\
\text { overcome. Discrimination and } \\
\text { cisgenderism presumption } \\
\text { apparent. }\end{array}$ & $\begin{array}{l}\text { into cis-genderism and } \\
\text { discriminatory experiences. }\end{array}$ \\
\hline $\begin{array}{l}\text { Shelton et al. } \\
\text { (2017) } \\
\text { USA }\end{array}$ & $\begin{array}{l}\text { Examine resilience } \\
\text { in homeless } \\
\text { transgender youth }\end{array}$ & $\begin{array}{l}\text { Transgender youth } \\
(\mathrm{n}=27)\end{array}$ & Interviews & $\begin{array}{l}\text { Resilience, resistance and } \\
\text { strength expressed despite } \\
\text { structural constraints and } \\
\text { oppression, despite cisgender } \\
\text { presumptions. Personal agency } \\
\text { shown through self-definition } \\
\text { and making own choices. } \\
\text { Challenges reframed as } \\
\text { positive experiences and } \\
\text { orientation towards an } \\
\text { envisioned future. }\end{array}$ & $\begin{array}{l}\text { Require a strength-based } \\
\text { framework and approaches in } \\
\text { practice. More research required } \\
\text { into all facets of transgender } \\
\text { experiences including variances } \\
\text { in resilience. Also, to explore the } \\
\text { intersection of race, gender } \\
\text { identity and expression amongst } \\
\text { trans people experiencing } \\
\text { homelessness. }\end{array}$ \\
\hline
\end{tabular}


Table 3: Methodological quality of qualitative studies using MMAT (Hong et al. 2018)

\begin{tabular}{|l|l|l|l|l|l|l|l|}
\hline & Q1 & Q2 & Q3 & Q4 & Q5 & Total & $\begin{array}{l}\text { Ratings: } \\
\text { (5-high, 3-4 } \\
\text { medium, } \\
\text { low) }\end{array}$ \\
\hline Blosnich et al. (2020) & Y & Y & Y & Y & Y & 5 & H \\
\hline Glick et al. (2019) & Y & Y & Y & Y & Y & 5 & H \\
\hline Lyons et al. (2016) & Y & Y & Y & Y & Y & 5 & H \\
\hline Mokonogho et al. (2010) & Y & Y & N & CT & CT & 2 & L \\
\hline Shelton (2015) & Y & Y & Y & Y & Y & 5 & H \\
\hline Shelton (2016) & Y & Y & Y & Y & Y & 5 & H \\
\hline Shelton \& Bond (2017) & Y & Y & Y & Y & Y & 5 & H \\
\hline Shelton et al. (2017) & Y & Y & Y & Y & Y & 5 & H \\
\hline
\end{tabular}

$\mathrm{Y}=\mathrm{yes}$, indicates a clear statement appears in the paper which directly answers the question;

$\mathrm{N}=\mathrm{no}$, indicates the question has been directly answered in the negative in the paper;

$\mathrm{CT}=$ can't tell, indicates there is no clear statement in the paper that answers the question

Critical appraisal questions were as follows:

1. Is the qualitative approach appropriate to answer the research question?

2. Are the qualitative data collection methods adequate to address the research question?

3. Are the findings adequately derived from the data?

4. Is the interpretation of results sufficiently substantiated by data?

5. Is there coherence between qualitative data sources, collection, analysis and interpretation? 
Table 4: Methodological quality of quantitative descriptive studies using MMAT (Hong et al. 2018)

\begin{tabular}{|l|l|l|l|l|l|l|l|}
\hline & Q1 & Q2 & Q3 & Q4 & Q5 & Total & $\begin{array}{l}\text { Ratings: } \\
\text { (5-high, 3-4 } \\
\text { medium, <3 low) }\end{array}$ \\
\hline Begun \& Katarri (2016) & Y & CT & Y & CT & Y & 3 & M \\
\hline Fletcher et al. (2014) & Y & CT & Y & CT & Y & 3 & M \\
\hline Johns et al. (2017) & Y & CT & Y & CT & Y & 3 & M \\
\hline Kattari \& Begun (2017) & Y & CT & Y & CT & Y & 3 & M \\
\hline
\end{tabular}

$\mathrm{Y}=\mathrm{yes}$, indicates a clear statement appears in the paper which directly answers the question;

$\mathrm{N}=\mathrm{no}$, indicates the question has been directly answered in the negative in the paper;

$\mathrm{CT}=$ can't tell, indicates there is no clear statement in the paper that answers the question

Critical appraisal questions were as follows:

1. Is the sampling strategy relevant to address the research question?

2. Is the sample representative of the target population?

3. Are the measurements appropriate?

4. Is the risk of nonresponse bias low?

5. Is the statistical analysis appropriate to answer the research question? 
